\title{
廃瓦を利用した燻し瓦の作製†
}

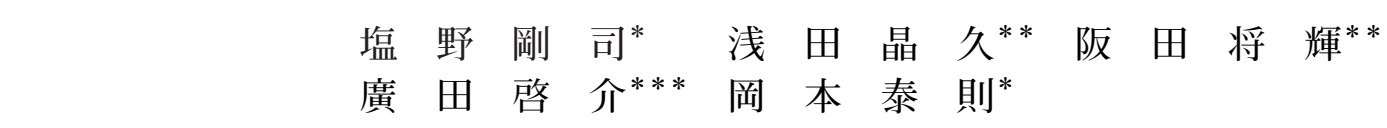

\section{Preparation of Smoked Roof Tiles Using Waste Roof Tile}

by

Takeshi Shiono *, Masahisa Asada ${ }^{* *}$, Masaki Sakata ${ }^{* *}$, Keisuke Hirota $^{* * *}$ and Yasunori Okamoto *

Porcelain roof tiles are very popular in Japan. In Kyoto, in particular, smoked roof tiles are preferred for temples, shrines and even home. A volume of roof tiles are taken out as an industrial waste, with building renovation and housing rehabilitation. Such tiles have been discarded in landfills in the past. Decrease in landfills and demand of reduction of such waste promote to recycle the waste roof tile. On the contrary, clay with good quality for roof tile is being depleted. In order to decrease fraction of roof tile clay used in producing the tile, in the preset study, waste roof tile was recycled for the production of the new tile. In consequence, green compacts with waste roof tiles were sintered by conventional method and the mechanical and water-resistant properties were improved. However, smoking process was insufficient. Beautiful smoked tiles could not be prepared, resulting from formation of glassy phase on the tiles. Control of sintering temperature makes it successful to prepare the tiles with almost the same shrinkage and water absorption of tile prepared with only roof tile clay without waste tile.

Key words : Roof tile, Smoking, Recycle, Water absorption, Strength

\section{1 緒言}

我が国の粘土瓦の製造技術 ${ }^{1}{ }^{1}$ は, 588 年に朝鮮半島の 技術者により導入され，現在まで 1400 年以上の歴史が ある。現在でも，粘土瓦は屋根葺き材の約 $56 \%$ を占めて いる，四方を海に囲まれる島国である我が国では多様な 気候条件に適用させるために瓦もそれぞれの地で産出さ れる粘土を用いて，その地に適した瓦に改良され，日本 全土に広まる結果となった，現在では原料となる粘土の 採掘事情から, 瓦の生産地が三河 (三州), 島根 (石州), 淡路の三つに集約されつつあるが，一部の地方でも生産 量は少ないものの，生産されている，中でも伝統的建造 物が多く存在する京都ではその技術が京瓦として伝えら れている.

京瓦とは，以前は原料打よび燃料調達，生産までをす べて京都に扔いて行っている瓦を指していたが，燃料が 松などの木材から化石燃料に移行し，原料である粘土に ついても採掘場の減少に伴い，現在では伝承された技術 を用いて京都で生産された瓦という定義にとどまってい る。京瓦の特徴としては，(1) 瓦の表面を職人の手作業 によって究極までに滑らかになるよう加工を施す「磨き (みがき)」，(2) 瓦表面に炭素のコーティングを行う「煹 し(燻化)」という工程をもち，(3) 瓦としては比較的高 温で焼成を行っていることなどが挙げられる。これらの 工程を経て作られた京瓦は滑らかな表面に良好な銀色光 沢をもつ燻し瓦として社寺仏閣などにおいて用いられて いる．特に「磨き」は職人に高い技術力を要求されるも
ので，朵の後の「煄し」による瓦表面の光沢，感触に大 きな影響を及ぼす。「磨き」は，職人がへラを用いて手作 業により表面を滑らかにする操作で，特に，「磨き」を表 面 3 回，裏面 2 回ずつ行い，焼成された瓦のことを，「本 ウス」瓦といい，京瓦の最高級品とされてきた。しかし， 採掘場の減少に伴い，良質な瓦用粘土の入手が困難にな り，「本ウス」瓦を作製できなくなってきたのが現状であ る、筆者の一人である浅田は, 原料の粘土を一部べトナ ムから輸入し，瓦を製造している。一方，住宅の建て替 え, リフォームに伴い多くの廃瓦が排出されている。こ れらの瓦は, 従来, 産業廃棄物として埋め立て処分され ている。しかし，埋め立て処分地の枯渇，廃葉物の減量 化の要請など，瓦の有効利用が望まれている。2) 5)星ら は,6)廃瓦を用いて釉薬瓦の開発を行っているが，燻し瓦 の作製に廃瓦を用いていた試みはほとんどないのが現状 である。

本研究では，廃瓦を原料の一部として再利用すること で原料となる瓦用粘土の使用量を削減させることを目的 とし, 廃瓦の添加が瓦の機械的性質や, 京瓦の特徵であ る「燻し」に与える影響を検討した。

\section{$2 \cdot 1$ 供試体瓦の作製}

\section{2 実 験 方 法}

Fig. 1 に廃瓦を利用した京瓦の作製プロセスを示す。 試料の原料として浅田製瓦工場より提供された瓦粘土 （三河粘土，山土，水簊，べトナム粘土の混合物）と廃 瓦を用いた．Fig. 2 は，原料の瓦粘土と廃瓦をX 線回折

$\dagger \quad$ 原稿受理 平成 23 年 6 月 24 日 Received June 24, 2011 (C) 2012 The Society of Materials Science, Japan

* 正 会 員 京都工芸繊維大学物質工学部門 †606-8585 京都市左京区松ヶ崎御所海道町, Dept. Chem. \& Mater. Tech,, Kyoto Inst. of Tech. Sakyo-ku, Kyoto, 606-8585

** 浅田製瓦工場 =612-8338 京都市伏見区舞台町, Asada Kawara Factory, Fushimi-ku, Kyoto, 612-8338

*** 京都工芸繊維大学物質工学部門 ７606-8585 京都市左京区松ヶ崎御所海道町, Dept. Chem. \& Mater. Tech,, Kyoto Inst. of Tech., Sakyo-ku, Kyoto, 606-8585 


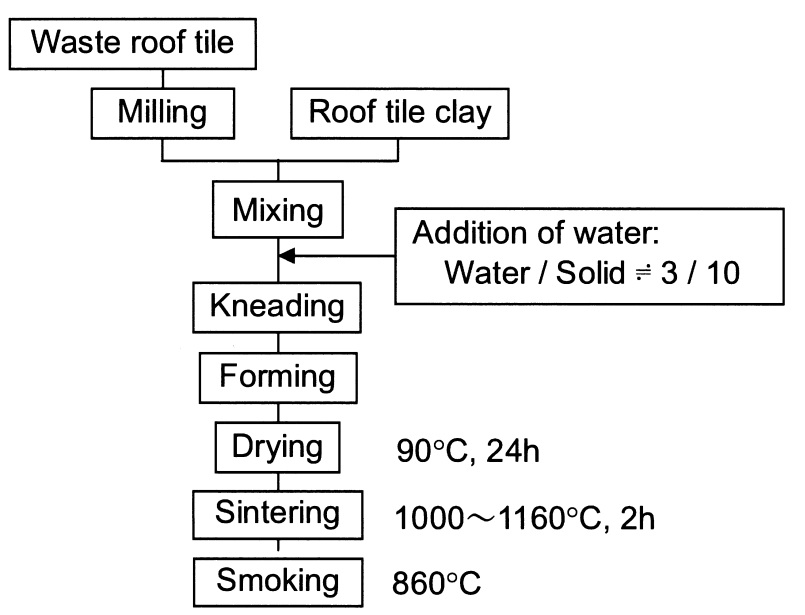

Fig. 1 Preparation of smoked roof tile.

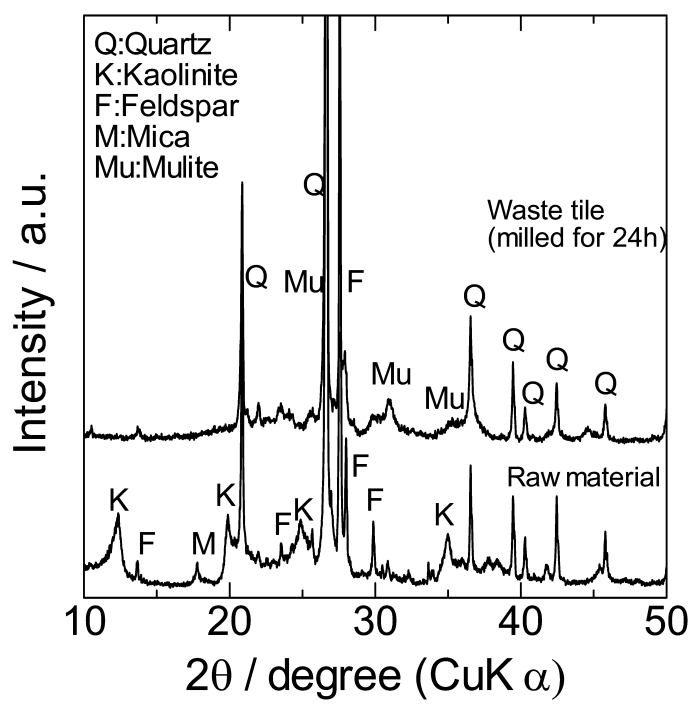

Fig. 2 X-ray diffraction patterns of raw materials for roof tiles.

分析した結果である.瓦粘土は石英を中心に, カオリン， 長石, 雲母から構成されていた。一方, 廃瓦は, カオリンや 長石の結晶相が認められず, 石英, ムライト相と $20^{\circ} \sim 30^{\circ}$ 付近にガラス相に起因するハローがわずかに観察された。 この廃瓦中のムライト相は, 製造時に原料として含まれ ていたカオリンが, 分解して生成されたものと考えられ る, またガラス相は長石が溶融, シリカ成分と反応して 生じたものと判断できる. 粘土瓦原料である廃瓦には数 $\mathrm{mm}$ 以下に粗砕されたものを用いた。この廃瓦を, 水を 分散媒としてアルミナボールを用いてそれれでれ 6 96 時 間ボールミルを行い, 赤外線ランプで乾燥し, 粉末を調 製した。 さらに 24,48 時間ボールミルした廃瓦については, 凝集をほぐすために目開き $500 \mu \mathrm{m}$ のふるいに通し，瓦用 粘土に対し $10 ， 30 ， 50 \mathrm{mass} \%$ になるように秤量し，重量 で水/固体比が約 $24 / 76$ で, 土練りした。この原料粘土 を石膏型を用いて，所定の大きさに成形した。成形体を 常温で半日乾燥後, さらに, $90^{\circ} \mathrm{C}$ 乾燥器で 1 日乾燥さ せた。焼成は電気炉で昇温速度 $5^{\circ} \mathrm{C} / \mathrm{min}$ で $1160^{\circ} \mathrm{C}$ まで温 度を上げ 2 時間保持の条件で行った。また, 一部試料に ついては, 浅田製瓦工場で, 通常の煄し瓦の製造と同じ プロセスで，廃瓦を含む成形体の焼成，熡しを行った。

\section{$2 \cdot 2$ 瓦素材の評価}

瓦に要求される重要な特性として, 防水性, 強度, 防 火性, 而久性などがある。本研究では, 防水性の評価と して，アルキメデス法による吸水率の測定を行なうと共 に, 機械的特性の評価として三点曲げ強度を評価した。 また，成形体からの収縮率を評価するために，成形直後 の直方体試料の三辺の長さおよび, 焼成後の試料の三辺 の長さを評価し，線収縮率を算出した。ボールミルによ る廃瓦の粒度の変化は，レーザ回折/散乱式粒度分布測 定装置（堀場製作所；LA-920）を用いて行った。

また，廃瓦を加えて作製した成形体に燻しを施し，廃 瓦の添加が燻しに及ぼす影響を調べた。

\section{3 実験結果および考察}

\section{$3 \cdot 1$ 廃瓦の粉砕}

ボールミルによる廃瓦の粉砕の効果を調べるために， 粒子径の変化を測定した結果を Fig. 3 に示す. 粉硒前の 廃瓦の粒子径が $26 \mu \mathrm{m}$ であったのが，ボールミル粉砕に よって, 粒子径は急激に減少し, 24 時間の粉砕で $4.7 \mu \mathrm{m}$ になった。この粒子径は，通常，京瓦の作製に使われて いる瓦粘土の粒子径である $4.7 \mu \mathrm{m}$ と同程度であることが 分かった。 また, 24 時間以上の粉研は著しい粒子径の減 少を起こさせないことが明らかになった。このように短 時間で微粒子ができたことの理由として, 瓦の焼結が通 常のファインセラミックのような拡散による緻密な焼結 プロセスによって作製されているのではなく，後で説明 するように, 粒子界面でのガラス相の形成によって焼結 しているためだと推察される。この結果を考虑し, 焼結 した瓦素地の物性に及ぼす粉砕の影響を検討した。以降 の実験は, 粒子径が顕著に減少した過程を調べるために, 粉砕時間が 6,15 時間の廃瓦, 1 日以上の粉砕では著し い粒子径の変化が認められなかったので, 粒子径が原料 の瓦粘土の粒子径 $(4.7 \mu \mathrm{m})$ より小さくなった粉砕時間 48 時間の廃瓦を使用し，評価を行った。 $6 \mathrm{~h}, 15 \mathrm{~h}, 48 \mathrm{~h}$ 粉砕時間の粒子径は, Fig. 3 より, それぞれ $18.7 \mu \mathrm{m}$, $8.8 \mu \mathrm{m}, 4.4 \mu \mathrm{m}$ と見積もられた.

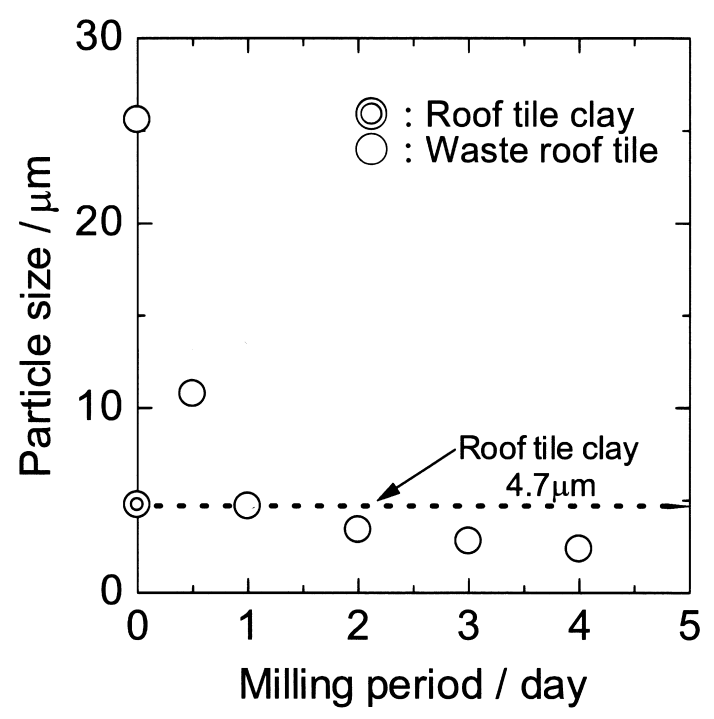

Fig. 3 Effect of milling for waste roof tile on particle size. 


\section{$3 \cdot 2$ 瓦の評価}

製品の瓦の寸法に大きな影響を与える線収縮率につい ての検討をおこなった. Fig. 4 は，所定の時間粉砕した 廃瓦に瓦粘土を混合して作製した成形体を， $1160^{\circ} \mathrm{C} て ゙$ 焼 成したときの線収縮率に及ぼす廃瓦の添加量の影響を調 べた結果である，図中の線収縮率は，成形直後の大きさ を基準としているため，乾燥による収縮および，焼成に よる収縮を含む。粉砕処理を行なわなかった廃瓦を用い た場合には，添加量を増やすと共に，収縮率は低下し $50 \mathrm{mass} \%$ 添加したときには約 $8.2 \%$ と瓦粘土のみで作製 したときに比べ $5 \%$ 近く収縮率が小さくなった。この原 因として, 廃瓦の粒子径が大きい場合には，その部分が すでに硬い凝結体となっているため，焼成温度になって も焼結が進行せず，収縮が促進されなくなっているもの と考えられる。一方，粉砕処理を行い粒子径が原料と同 程度にまで小さくなった廃瓦を用いた場合には，瓦粘土 を同じように焼結が進行したものと判断できる。また， ボールミルを 15 時間行った試料では原料の瓦粘土のみ の試料と同程度の線収縮率を示しているのが分かり，廃 瓦の配合によっては原料粘土と近い值を得られることが 分かった４8 時間ボールミルを行った廃瓦を用いても， 15 時間の場合と著しい差はみられなかった。また，成形 体から乾燥後までの収縮を調べた結果，粉砕時間にかか わらず，廃瓦の添加が増加するにしたがって線収縮率が 減少していた。これはすでに焼結している廃瓦を混合し ているため，成形体の収縮に関与している粘土成分の割 合が少なくなったためだと判断できる.

次に瓦の機能を考える上で重要なパラメータである吸 水率を評価した. Fig. 5 に Fig. 4 で得られた試料の吸水 率の結果を示す。吸水率はアルキメデス法によって測定 した. 粉砕処理を行なわなかった場合には, 廃瓦の添加量 の増加と共に吸水率は大きくなり瓦には適していないこと が示唆された。これはFig. 4 の収縮率の変化からも分か るように粉砕処理しないと収縮が小さくなり，成形時の 気孔がそのまま多く存在するために吸水率が高くなったと 考えられる。一方, 粉砕処理により吸水率は著しく減少 し，耐水性の優れた瓦の作製できることが示唆されたが， 後で述べるように，実際に燻化の处理を行なうとほとん

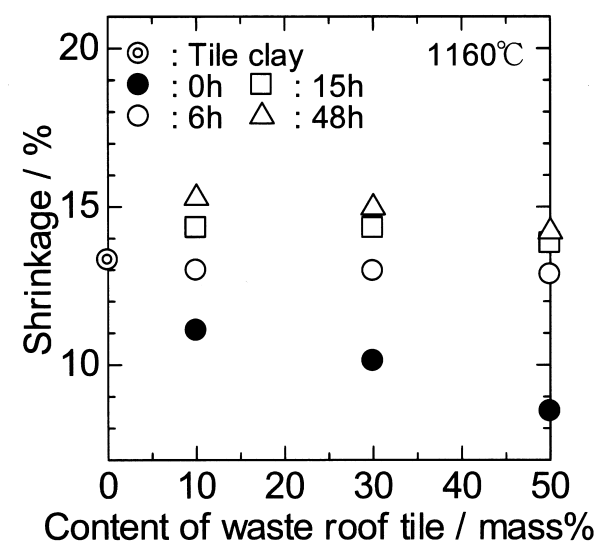

Fig. 4 Effect of milling time of waste roof tile on shrinkage, as a function of the roof tile content. (Milling time : $0 \mathrm{~h} \bigcirc, 6 \mathrm{~h} \bigcirc, 15 \mathrm{~h} \square, 48 \mathrm{~h} \triangle$ )

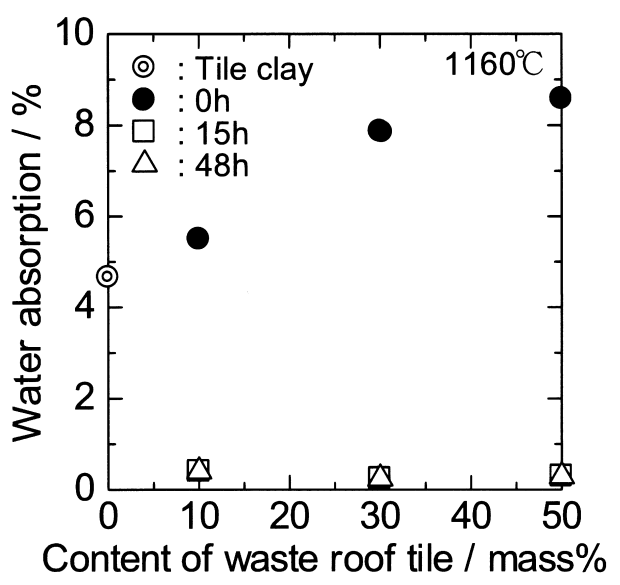

Fig. 5 Effect of content of waste roof tile and milling time on water absorption of sintered tile. (Milling time : $0 \mathrm{~h} \bullet, 15 \mathrm{~h} \square, 48 \mathrm{~h} \triangle$ )

ど炭素がコーティングされず，焼結体の内部にも炭素の 入らないことが明らかになった。この原因としてガラス 相の生成の可能性が考えられた (Fig. 6)。すでに述べた ように瓦の焼結は粒子間でのガラス相の生成によって進 行する。瓦粘土のみを出発原料とする場合，原料中には ガラス相はなく焼成温度でガラス相の生成が起こる。一 方，廃瓦を添加すると，すでに一度生成したガラス相も 添加することになり，焼成温度ではかなり多くのガラス 相が存在するものと考えられる。ささに，浅田製瓦工場 で作製している瓦は $1160^{\circ} \mathrm{C} て ゙$ 焼成が行なわれており，通 常の瓦の焼成温度より $100^{\circ} \mathrm{C}$ 近く高い。そのため廃瓦を 用いた場合には，多くのガラス相が生成し吸水率が著し く小さくなったものと思われる。ボールミルの時間につ いては，15時間，48時間いずれの場合も，吸水特性に 顕著な差は認められなかった。

Fig. 6 は，廃瓦の添加量を変化させ作製した焼成体の 結晶相を X 線回折分析で調べた結果である.ムライト相 およびガラス相に特有な $20^{\circ} \sim 30^{\circ}$ にかけてハローと呼 ばれるブロードなピークがはっきりと認められ, 前述し たようにガラスの生成が確認できる。さらに，廃瓦の添 加量を増やしても結晶相に大きな変化は認められなかっ

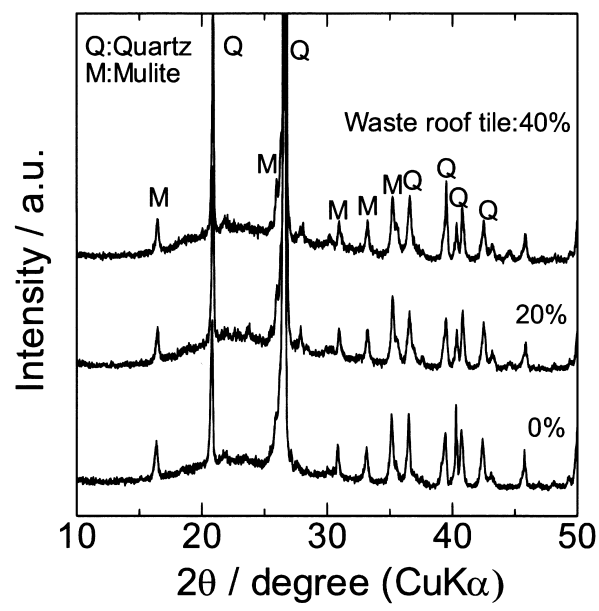

Fig. 6 Crystalline phase of sintered tile with different amount of waste roof tile. 
た。しかし，廃瓦の添加量が多いほど，八ローの面積が 大きく，カラス相が多く生成していることが認められ， この結果は吸水率の特性が廃瓦の多い方が向上していた ことを支持しているものと考えられる。また，原料の瓦 粘土中に存在していた長石，カオリンが消失し，石英は 焼成後でもクリストバライトやトリジマイトに転移せず， 石英として存在していた。

このようなガラス相の形成は破壊挙動にも大きな影響 を与えると考えられる．Fig. 7 は，廃瓦の添加量を変え て作製した焼結体の三点曲げ強度を測定した結果である。 配合率 10mass\% の時点ではボールミルの有無に大きな差 はみられなかった。しかし，廃瓦を 30mass\% 以上添加し た場合，ボールミルを行っていない廃瓦を混合した試料 についてはその混合量が増加するにしたがい，強度の減 少が認められた。これは粒度の大きな廃瓦が試料表面に おいて破壊源となりうるために, 強度が減少したものと 考えられる。一方でボールミルを行った廃瓦を混合した 試料についてはその配合量が増加するに従って強度が向 上していることがわかる。また, 試料間での密度の差が ほとんどないことからボールミルを行った廃瓦を配合し た試料表面の緻密化が推測された。これも試料表面にお いてガラス相が生成したことで破壊源となるき裂が抑制 されたことによると考えられる。

Fig. 8 は，瓦粘土にボールミルした廃瓦を混合して作 製した成形体を， $1160^{\circ} \mathrm{C}$ で焼成した試料(左側)と，さら に，燻しを施した試料（右側）の外観である。廃瓦を添 加していない瓦粘土のみの試料に対し，廃瓦を混合した 試料はその配合量が増加するにしたがい，その表面に光 沢を帯びていることがわかる，また，瓦粘土のみの試料， ボールミルを行った廃瓦を混合した試料共に，成形体の ときには表面は比較的滑らかであったが，焼成後は表面 に小さな粒が浮き出てザラザラとした感触であった。廃 瓦の配合により，粒は小さくても，その感触が消失する ことはなかった。 これは，粘土成分が焼成により収縮し， 原料に含まれていた石英や，廃瓦などの収縮しない成分 が焼成により，表面に浮き出たものと判断できる.

次にこれらの試料について燻し（燻し：表面に炭素を

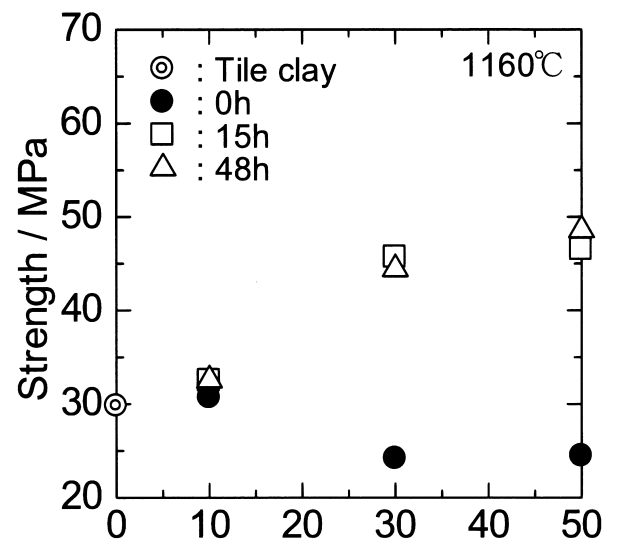

Content of waste roof tile / mass $\%$

Fig. 7 Effect of content of waste roof tile and milling time on 3-point-bending-strength of sintered tile. (Milling time : $0 \mathrm{~h} \bigcirc, 6 \mathrm{~h} \bigcirc, 15 \mathrm{~h} \square, 48 \mathrm{~h} \triangle$ )
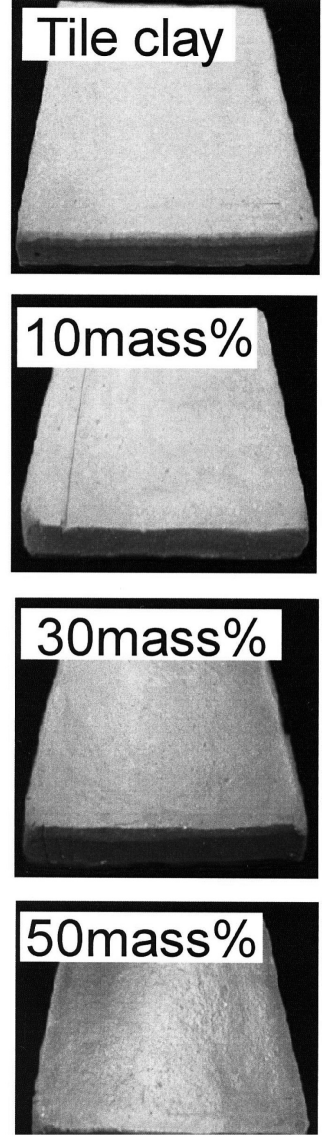

Fig. 8 Effect of addition of waste roof tile on appearance of as-sintered tiles (left) and as-smoked tiles (right).

コーティングするプロセス）を行ったところ，粉砕を行っ た廃瓦を混合した試料には炭素がうまくのらず，表面が 黒くなるにとどまった。また，瓦粘土のみの試料では手 で擦ってみたり，爪を立てて引つ掻いても銀色膜がはがれ ることはなく，強固な膜が生成していることが分かった。 一方，ボールミルを行った試料は同様の操作をすると銀 色膜がパラパラとはがれ落ちてしまった。これは試料表面 が緻密すぎたことにより炭素の沈着が不充分であったため と考えられる．このことからも表面をガラス相が覆って いたものと推測された。廃瓦を添加することにより，吸 水率, 強度において高い数值を示したが, 京瓦として利 用できないことが明らかになった。

\section{$3 \cdot 3$ 焼成温度の検討}

今までの評価から，ボールミルを行った試料について ガラス相の形成を防ぐことが必要であることが明らかに なった，通常，瓦は $1000 \sim 1200^{\circ} \mathrm{C}$ 温度範囲で焼成され る。ガラス化は瓦の焼結にとって重要な役割をもち，前 述のと抢り反応により $1000^{\circ} \mathrm{C}$ 以下で起こるものと考えら れる。また，温度を上げていくことでガラス化を起こす 物質の量は増加していくと推察される。これにより焼成 温度を下げることで過度のガラス化を防ぎ，なおかつ適 度な焼結がなされる焼成温度の検討が必要である。そこ で，ガラス相の形成に大きな影響を与える焼成温度につ いての評価を行った.

焼成温度を $1000^{\circ} \mathrm{C}, 1100^{\circ} \mathrm{C}, 1160^{\circ} \mathrm{C}$ とて，乾燥か ら焼成までの線収縮率を測定した結果を Fig. 9 に示す。 


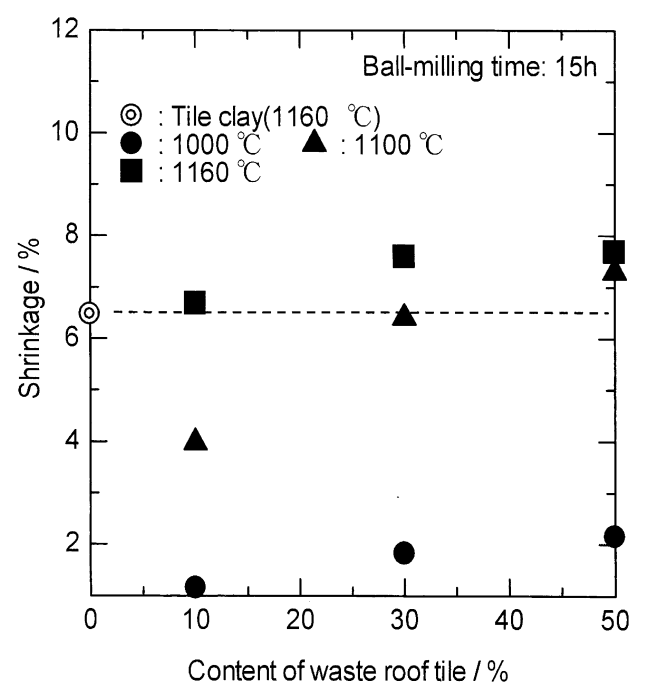

Fig. 9 Relationship between shrinkage of sintered tile and content of waste roof tile at various sintering temperature.

$1000^{\circ} \mathrm{C}$ で焼成した場合，線収縮率が非常に小さく焼結が 進んでいないことがわかる。そこで， $1100^{\circ} \mathrm{C} て ゙$ 焼成した ところ原料の瓦粘土のみの試料と同程度の線収縮率を示 すことが確認された.特に，配合率 30\% の試料では線収縮 率が瓦粘土とほほ同じ值を示した。さらにボールミルを 行った廃瓦の配合量が増加するにしたがって線収縮率が 増加していることがわかる。このことから既に一度焼結 されている廃瓦を混合することで試料全体の焼結が促進 されることが分かった。

廃瓦を用い瓦の焼成を行った場合，粉砕処理すること によって耐水性の優れた焼結体を作製することができた。 しかし，素焼きの状態で表面にガラス相が形成されると， 京瓦特有の燻化を行っても表面, 内部に炭素をコーティ ングできない，そこで，焼成温度を変化させ，焼結体の 作製を行った. Fig. 10 は，15 時間粉碳処理した廃瓦を 種々の温度で焼成したときの吸水率を示す. $1000^{\circ} \mathrm{C}$ の焼 成では，吸水率が瓦粘土単味で作製したものに比べて大 きく，焼結があまり進んでいないことを示している。一

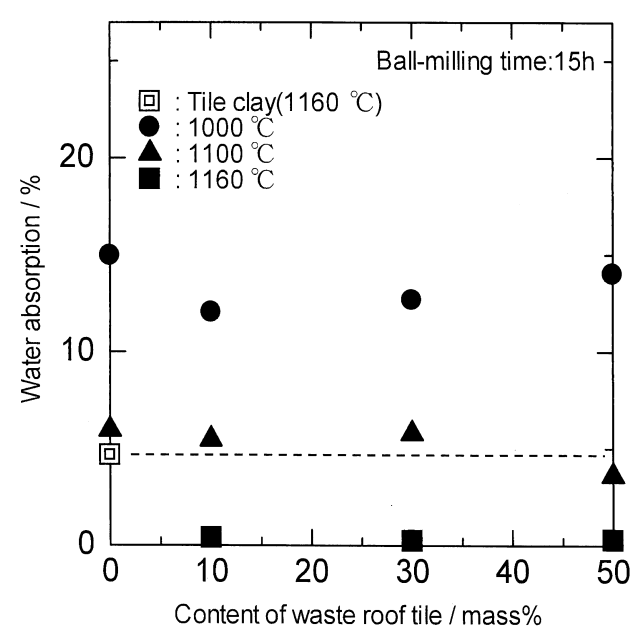

Fig. 10 Relationship between water absorption of sintered tile and content of waste roof tile at various sintering temperature.
方， $1100^{\circ} \mathrm{C}$ 焼成では，ほぼ瓦粘土の焼成品と同程度の吸 水率が達成でき，廃瓦を使うことによって $1100^{\circ} \mathrm{C} て ゙$ 焼成 できることが分かった，また，添加量を増やすことによっ て吸水率がわずかに小さくなっているのは，ガラス相の 量に起因するものだと考えられる。実際，吸水率の低い 試料ほど表面のざらざら感は減少し，ガラス的な光沢が 認められた。焼成温度を下げることにより過度のガラス 相の生成を防ぐことができ, 廃瓦を多く添加しても適度 な焼結および燻化きることが明らかになった。

次にボールミル 15 時間の廃瓦を配合し $1100^{\circ} \mathrm{C}$ で焼成 を行った試料について強度を測定した結果を Fig. 11 に 示す。ボールミルを行った廃瓦の混合が有用であること はすでに述べたが, $1100^{\circ} \mathrm{C} て ゙$ 焼成を行いガラス相の形成 を抑制した試料でも瓦粘土のみの試料の強度を上回るこ とが確認された。ささらにその配合量を増加させるにした がって, 強度が向上していることも分かった。これは廃 瓦の混合により内部で適度なガラス化が起こったためと 考える。このことからボールミルを行った廃瓦を配合し， 現在, 実際に製造されている焼成温度より, 低い $1100^{\circ} \mathrm{C}$ で焼成を行うことで, 瓦粘土のみの試料と同程度の吸水 率を示し，さらに，瓦粘土を上回る強度を示すことが確 認された。そこで, 15 時間ボールミルを行った廃瓦を用 いて，廃瓦添加量が $50 \% ， 30 \%$ の成形体を作製， $1100^{\circ} \mathrm{C}$ で焼成後，燻しを行った。 Fig. 12 は燻された試料の外

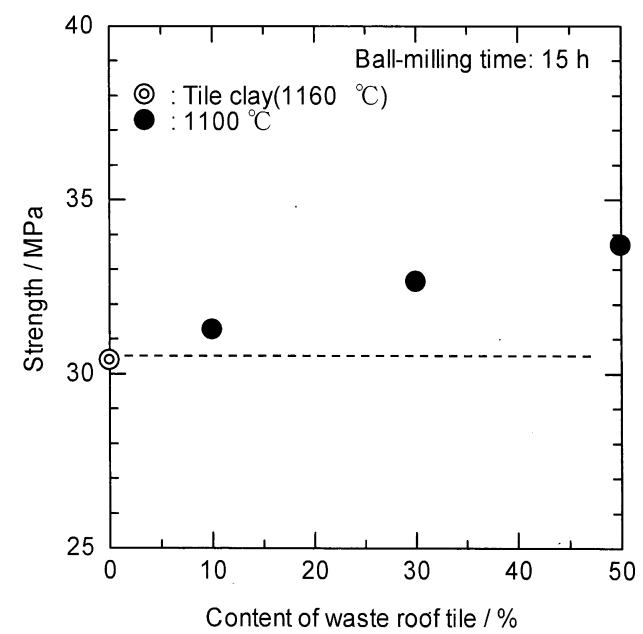

Fig. 11 Effect of content of waste roof tile and milling time on 3-point-bending-strength of sintered tile.

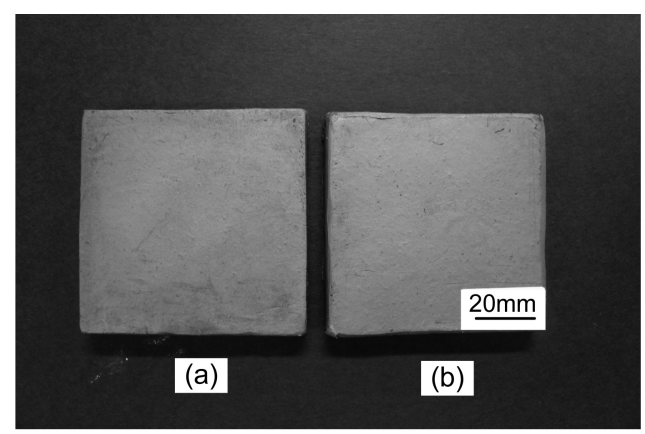

Fig. 12 Photographs of smoked tiles prepared with different content of waste roof tile milled for $15 \mathrm{~h}$. Content of waste tile : $50 \%$ (a) and $30 \%$ (b). 
観である. Fig. 8 で観察されたような燻しがのらない， 炭素膜の剥げ落ちは観察されなかった。また，セロテー プを密着させ，剥がすことにより炭素膜の密着性を評価 した，定量的な評価は難しいが，瓦粘土を用いて作製し たものと同程度の密着性を示した。すなわち，焼成温度 を下げ，ガラス相の生成を抑えることにより，原料の一 部に廃瓦を使用しても燻し瓦を作製できることが明らか になった。

\section{4 結 言}

本実験では，廃棄が問題となっている古瓦を瓦粘土に 添加し，焼成された瓦素材の機械的特性を評価すること により，瓦のリサイクルを検討した。その結果，以下の 知見を得た。

・廃瓦を添加した成形体を，現在，実際に焼成を行って いる焼成条件で焼成した場合，強度，吸水率など瓦の 機能として必要な特性は向上することが明らかになっ たが，試料表面にガラス相が形成され，京瓦の特徴の 一つである「燻し」がうまく施すことができず。京瓦 として利用できないことがわかった。

・次にガラス化を抑制するために, 焼成温度を変えて行っ た結果，焼成温度を $1100^{\circ} \mathrm{C}$ に低下させることによっ て，線収縮率，吸水率が原料の瓦粘土を単味で用いた 場合と同程度の瓦を作製することができ，燻しも施せ ることが明らかになった。ささらに強度については，廃 瓦を添加することにより，瓦粘土単味の試料より高い 值を得ることに成功した。

・ 二次的な成果であるが，廃瓦を添加することにより， 焼成温度を下げるという省エネルギー化の可能性も示 唆された.これはすでに一度焼結がなされている廃瓦の ガラス相が，大きく寄与しているものと判断できた.
すなわち，廃瓦中のガラス相が $1000^{\circ} \mathrm{C}$ 以下で軟化し， 瓦の焼結がより低い温度でも促進されたと推察できる.

・本研究を通して，廃瓦を燻し瓦の製造に適用できるこ とが明らかになった。ただし，廃瓦が製造された産地 によって，瓦の結晶相およびガラス相の組成や構成割 合が異なる可能性があり，実際に廃瓦を利用する場合 には，それらの知見を十分吟味する必要がある。

\section{参 考 文 献}

1) J. Sato, "Kawarato yanekouzou", p.137 (1983) Gakugei-shuppansha.

2) M. Okazaki, T. Horikoshi, I. Tanaka and Y. Uno, "Thermal characteristic of pavement using recycling kawara-tiles", Report of Tokai Branch of Architectural Institute of Japan, No.42, pp.357-360 (2004).

3 ) T. Utsuki and M. Nishimura, "Research for recycling promotion of ceramic roof tiles wastes", Fukushima-ken haitekupuraza heisei21nendo kennkyuuhoukokusho, pp.1-4 (2009).

4) H. Tomotake, T. Shimizu, K. Sakamoto and K. Torii, "Haikawarasaiseikotsuzaiwo shiyousita konkuri-toseihinno shoseishitu”, konkuri-to kougaku nenjironbunshuu, Vol.25, No.1, pp.1355-1360 (2003).

$5)$ K. Abe, K. Ando, N. Esumi, T. Harada and T. Egi, "Kawarafunnsaibutuwo kotsuzaitoshita konkuri-tono seizounarabini hyoukasiken”, Report of the Shimane Institute for Industrial Technology, No.47, pp.11-15 (2011).

6 ) K. Hoshi, K. Sakakibara, M. Fukazawa and Y. Yamada, "Development of roofing tiles by recycled waste roofing tiles”, Report of Aichi Industrial Technology Institute, No.5, pp.112-15 (2006). 